[Agr. Biol. Chem., Vol. 29, No. 9, p. 885 887, 1965]

\title{
Purification of the 7S Component of Soybean Proteins
}

Sir:

Ultracentrifugal studies ${ }^{1.2)}$ on the waterextractable soybean proteins have revealed four fractions with sedimentation constants of about 2, 7, 11 and $15 \mathrm{~S}$ at $\mathrm{pH} 7.6,0.5$ ionic strength. Among them, the 11S component has been extensively studied ${ }^{3 \sim 8)}$ and purified ultracentrifugally from the cold-insoluble fraction by gel filtration. ${ }^{\text {" }}$

However, the 7S component has not been studied so much. Recently, Roberts and Briggs $^{10)}$ obtained a $7 \mathrm{~S}$ protein preparation of about 90 per cent ultracentrifugal purity by ammonium sulfate fractionation and gel filtration and discussed its characteristic properties.

The present communication is concerned with purification of the $7 \mathrm{~S}$ component of soy- bean proteins by cooling, addition of calcium chloride and gel filtration.

A standard buffer (a phosphate-sodium chloride buffer, $\mathrm{pH} 7.60,0.5$ ionic strength containing $0.01 \mathrm{~m}$ mercaptoethanol) was used as eluant in gel filtration and as solvent in ultracentrifugation. The $2 \mathrm{~S}$ contaminant was eliminated from the crude $7 \mathrm{~S}$ protein, which was prepared by the method shown in Fig. 1, by gel filtration with Sephadex G-100 (3.0× $90 \mathrm{~cm}$ column) as shown in Fig. 3B. Subsequently, a single peak was obtained by repeating gel filtration with Sephadex G-200 $(2.0 \times 200 \mathrm{~cm}$ column) three times as shown in Fig. 2C. The effluent was concentrated in a cellophane tubing under a pressure with Sephadex G-25. As shown in Fig. 3D, the purified $7 \mathrm{~S}$ protein by gel filtration exhibits

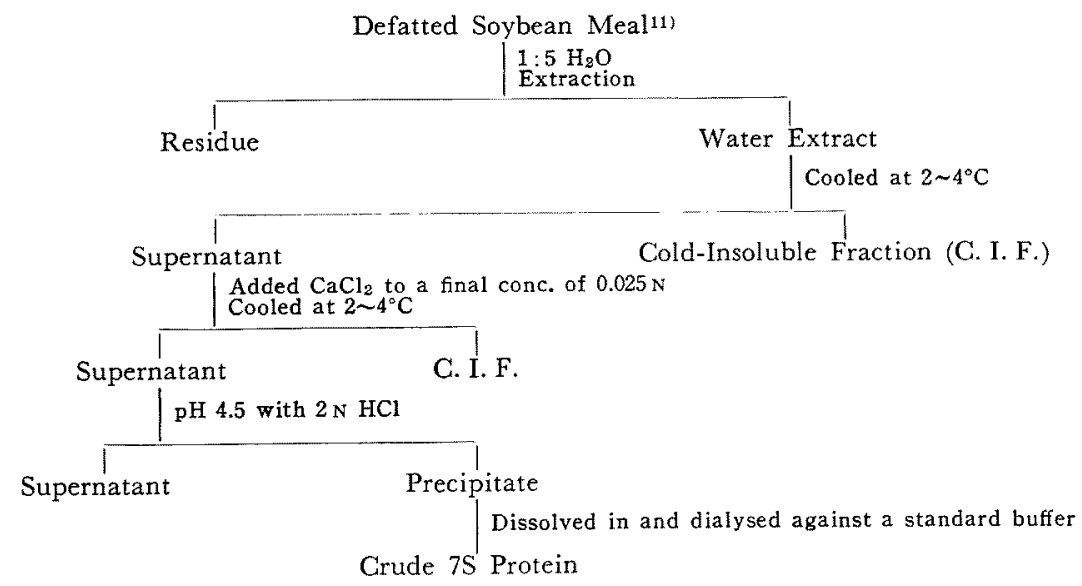

FIG. 1. Schematic Outline of the Preparation of the Crude 75 Protein.

1) W.E.E. Naismth, Biochim. Biophys. Acta, 16, 203 (1955).

2) W.J. Wolf and D. R. Briggs, Arch. Biochem. Biophys.,

63, 40 (1956).

3) W. J. Wolf and D. R. Briggs, ibid., 85, 186 (1959).

4) W.J. Wolf and D.R. Briggs, ibid., 76, 377 (1958).

5) D. R. Briggs and W. J. Wolf, ibid, 72, 127 (1957).

6) W.J. Wolf, G. E. Babcock and A.K. Smith, ibid., 99 , $265(1962)$.
7) V. L. Kretovich, T.I. Smirnova and S. Ya Frenkel, Biokhimiya, 23, 135 (1958).

8) V.L. Kretovich, T. I. Smirnova and S. Ya Frenkel, ibid., 23, 547 (1958).

9) H. Mitsuda, T. Kusano and K. Hasegawa, This Journal, 29. $7(1965)$.

10) R C. Roberts and D. R. Briggs, Cereal Chem., 42, 71 (1965).

11) I. Koshiyama and N, Iguchi, This Journal, 29, 144 (1965). 


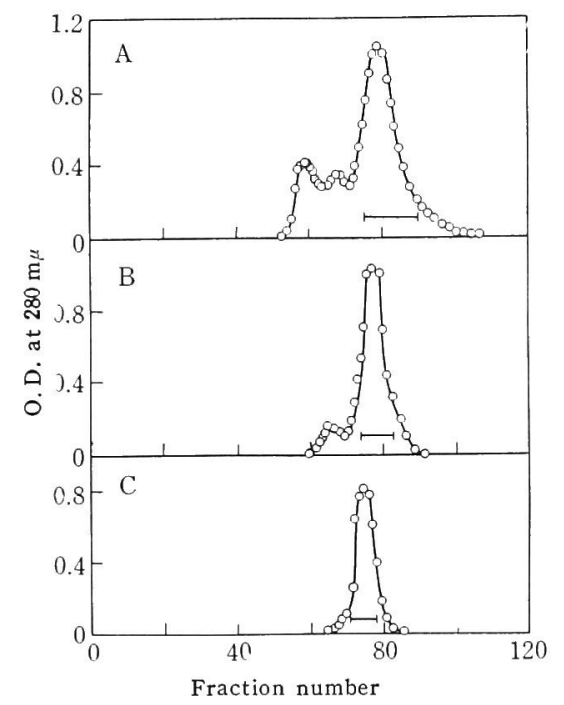

FIG. 2. Purification of the 7S Protein by Gel Filtration with Sephadex G-200.

A: First step gel filtration of the partially purified $7 \mathrm{~S}$ protein with Sephadex G-100.

B: Rechromatography I.

C: Rechromatography II

Each $5 \mathrm{ml}$ effluent was collected.
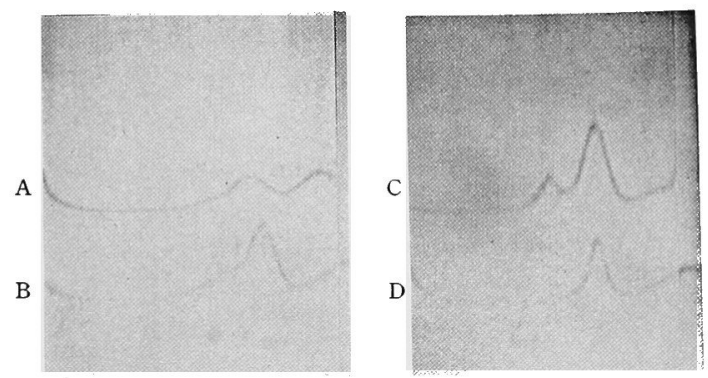

FIG. 3. Ultracentrifugal Patterns of Each Purification Step.

A: The crude $7 \mathrm{~S}$ protein.

B: The partially purified $7 \mathrm{~S}$ protein with Sephadex G-100.

C: The partially purified $7 \mathrm{~S}$ protein with Sephadex G-200 shown in Fig. 2A.

D: The purified $7 \mathrm{~S}$ protein shown in Fig. 2C.

Photographs were taken after $45 \mathrm{~min}$. of centrifugation at 55430 r.p.m. Direction of sedimentation is from right to left.

a single peak ultracentrifugally and has $\mathrm{S}_{20, \mathrm{w}}$ value of 7.61S. Fig. 4 shows electrophoretic patterns of the purified $7 \mathrm{~S}$ protein at $\mathrm{pH} 7.50$ (a phosphate-sodium chloride buffer, 0.1 ionic

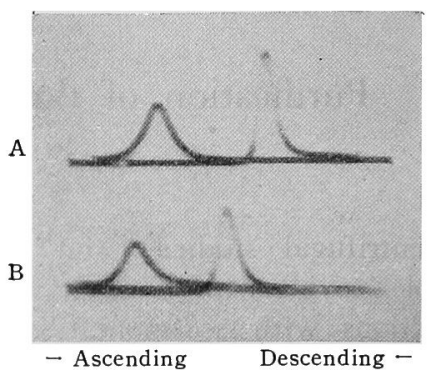

FIG. 4. Electrophoretic Patterns of the Purified 7S Protein.

A: Taken at $2 \%$ protein concentration after $91 \mathrm{~min}$. in pH 7.50 buffer at $6 \mathrm{~mA}, 4^{\circ} \mathrm{C}$.

B: Taken at $1.2 \%$ protein concentration after $100 \mathrm{~mm}$. in $\mathrm{pH} 9.50$ buffer at $6 \mathrm{~mA}, 4^{\circ} \mathrm{C}$.

strength) and at $\mathrm{pH} 9.50$ (a glycine-sodium hydroxide-sodium chloride buffer, 0.1 ionic strength).

Considering the above-mentioned results, the purified 7S protein seems to be homogeneous ultracentrifugally and electrophoretically.

Naismith and Roberts et al. tried to purify the $7 \mathrm{~S}$ component of soybean proteins by various methods. However, they could not obtain the pure preparation, and discussed isomerization of the $7 \mathrm{~S}$ protein using an impure sample.

To this purifying procedure of the $7 \mathrm{~S}$ component of soybean proteins is applied the fractionating method $^{3)}$ of the $11 \mathrm{~S}$ protein from the aqueous extract of soybean meal. The I1S contaminant, which could not be eliminated by Roberts, was removed by gel filtration with Sephadex G-200.

Hasegawa et al. ${ }^{12)}$ isolated four 7S proteins, which had sedimentation constants calculated for 7.8, 7.5, 7.2 and $6.0 \mathrm{~S}$ respectively. The purified $7 \mathrm{~S}$ protein of this study may be one of them, but this assumption is not proved yet.

The author wishes to express his sincerest thanks to Prof. Y. Sakurai, Assist. Prof. M. Fujimaki, Prof. K. Arima and Prof. Y. Ikeda of the University of Tokyo for their kind guidance

12) K. Hasegawa, T. Kusano and H. Mitsuda, This Journa1, 27, 878 (1963). 
and valuable suggestions. Thanks are due to Department of Agricultural Chemistry, the University of Tokyo, for ultracentrifugal analysis. The author also wishes to thank Dr. M. Mogi, Dr. N. Iguchi and Mr. E. Ichishima for their kind advices and encouragements and Miss. T. Ichikawa for her kind assistance. Ikunori Koshryama

Noda Institute for Scientific Research, Noda City, Chiba-ken

Received July 8, 1965 